\section{OXBRIDGE UNDER FIRE}

\section{Camford Observed}

By Jasper Rose and John Ziman. Pp. 255. (London: Victor Grollancz, Ltd., 1964.) 25s. net.

$\mathrm{A}^{\mathrm{T}}$ T a time when our two ancient English universities are being subjected to widespread critical scrutiny it is useful to have this authentic account of what they are, what they do and how they do it. Many problems confront them in the modern world. Oxford and Cambridge have been undor heavy fire, not so much because of their shortcomings, but because they are regarded as homes of privilege and exclusiveness. This is anachronistic in an egalitarian age. It is asserted-and disputedthat in admitting students unfair preference is given to pupils from public schools. Attention has also been directed to the high proportion of appointments in the public services that go to Oxbridge graduates and to the allegedly favourable conditions of service which the older universities are able to offer to their academic staff. Holders of College fellowships have also been criticized for their reluctance to take senior positions of responsibility in the newer universities.

Some of this disquiet was stimulated by the report of the Robbins Committee, which referred to the conviction that teaching staffs at Oxford and Cambridge are more generously remunerated than those at other universities; to "the number of times when it is necessary to except Oxford and Cambridge from general statements about British universities"; and to "anomalies which may well not only endanger their own welfare but also the effectiveness of the whole system of higher education". In regard to remuneration, the air has been cleared by the recent report of the National Incomes Commission (Cmnd. 2317), which devotes a whole chapter to detailed information about the salary position at Oxford and Cambridge and concludes that if there is any problem it is for the Universities themselves and the University Grants Committee to examine and resolve.

The two universities have made moves to meet the Robbins criticisms. They are re-examining their administrative procedures and the relationships of the universities to the colleges. They have also taken the welcome step of expressing a wish to be associated with the proce. dures of the Universities Central Council on Admissions. Ostensibly the Robbins philosophy seems to be aimed at the unification of higher education. In fact, in the long run, it is much more likely to lead to a stratified system of universities, with Oxford and Cambridge remaining pre-eminently at the peak.

Mr. Rose and Dr. Ziman have written a very readable and informative book about Oxbridge. Its title seems to represent a mild protest by Cambridge men against the way in which Oxford is generally accorded precedence. Mr. Rose is a humanist and Dr. Ziman a scientist. A product of the 'brain drain' from New Zealand, Dr. Ziman read mathematics at Balliol before becoming a lecturer at the Cavendish Laboratory. He has been elected to the chair of theoretical physics at Bristol. Mr. Rose has taught in Keele and also in Texas, so that both authors have experience outside Oxbridge.

They describe the techniques used by the colleges for the selection of students, the life of the undergraduates and the dons, and the methods of teaching, in college and in university. There is a particularly illuminating account of the way in which college tutorials are conducted. So much depends on the personality of the tutor and on the establishment of a bond of sympathy with his student. Acedemic failure, a cause of so much concern at the newer universities, is minimal at Oxbridge. This depends on a number of factors which are clearly outlined. Not least is the system of degree classification.

From the chapter on postgraduate research ("Limbo") one gathers that the arts research student fares much more badly than his science counterpart. The association of a postgraduate student with a college is much more tenuous than that of an undergraduate. For the science student this is compensated by the community life of the laboratory. The authors also describe the procedures for election to research fellowships and teaching fellowships, with the responsibilities and privileges which accrue. The very unsatisfactory situation which has arisen from the expansion of university teaching staff with no corresponding increase in college fellowships has presented one of the problems which have yet to be resolved. Attention is also directed to the high degree of academic inbreeding at Oxbridge, less pronounced in the case of university appointments, especially to chairs, than with college fellowships. Many of the present difficulties arise, of course, from the co-existence of independent self-supporting colleges governed by Master and Fellows elected in perpetual succession with the university, maintained almost entirely from public funds but with limited jurisdiction over the body of undergraduates. The inherent weakness of the central university administration is also exposed by the authors. But any suggestion-and there have been such suggestions-that Oxford and Cambridge should becomo specialized postgraduate universities is completely discounted. "The colleges would fight it to the death."

This book is a brilliant satire which pillories sardonically the weaknesses and blemishes of the two ancient universities while tacitly assuming their excellence and superiority in so many respects. There is no suggestion that their academic and administrative structures should or will be demolished. Rather, they should be remoulded to correspond more closely with modern needs and conditions.

JAMES COOK

\section{ABSORPTION AND DISTRIBUTION OF DRUGS}

\section{Absorption and Distribution of Drugs}

Based on a Symposium held by the Association of Medical Advisers in the Pharmaceutical Industry. Edited by T. B. Binns. Pp. xi +270 . (Edinburgh and London: E. and S. Livingstone, Ltd., 1964.) 37s. $6 d$.

MANY pharmaceutical companies have always regar1 ded studies on the absorption, distribution and fate of a potential drug as an essential part of pre-clinical trial investigations, and legislation now being introduced would appear to make it obligatory to obtain some evidence on this aspect of the propertios of a potential drug. The Association of Medical Advisers in the Pharmaceutical Industry, by organizing a symposium on this topic, has rendered a valuable service to all, laboratory and clinical workers, concerned with the development of potential drugs.

The first papers on the absorption and distribution of drugs appeared in the scientific literature around the turn of the present century, following the introduction of chloroform, and most of the work published in the early years of this century was concerned with the factors which influence the uptake of the inhalation anæsthetics. From work reported in the past ten years it is now possible to predict with a fair degree of accuracy the distribution in the tissues and the rate of absorption and excretion of a new volatile anæsthetic. The absorption of drugs from the alimentary canal is usually more complex and the publishers of the proceedings of this symposium have misjudged the extent of our knowledge on this topic when they say that the factors which determine the absorption, distribution and fate of drugs have gradually been elucidated. Considerable progress is, however, being made and the papers presented at this symposium give the reader an opportunity to judge the state of the field for himself. 